\title{
Railway line capacity methods analysis and their application in "Lithuanian Railways" justification
}

\author{
Larisa Valentinoviča ${ }^{a}$, Henrikas Sivilevičius ${ }^{\mathrm{b}}$ \\ ${ }^{a}$ AB "Lietuvos Geležinkeliai" Railway Infrastructure Directorate. Traffic Management Systems Care Center engineer affiliation, \\ Geležinkelio str.16, Vilnius LT-02100, Lithuania \\ ${ }^{b}$ Vilnius Gediminas Technical Universit, Faculty of Transport Engineering, Department of Transport Technological Equipment, \\ Plytines str.27, Vilnius LT-10105, Lithuania
}

\begin{abstract}
This article is aimed at analyzing different methods of calculation of railway capacity of lines and applying them in "Lithuanian Railways", improving efficiency of railroad traffic management by using new and modern technologies, integrated into the new Traffic Management Centre (TMC) and its related systems, allowing the compression of railroad traffic schedule and facilitating conflict resolution during planning time by using new technologies. To assure new traffic prevision for "Lithuanian Railways", a new calculation method must be used, as today it is being used an old analytical method for capacity calculation on railway line, and this old calculation method does not allow the optimization of the use of the railway network. It is necessary to analyze new programming methods for calculating the train graph and its compression to adopt it in order to optimize the use of the network. This paper will present three methods used for calculating capacity consumption on railway lines and the results of applying one of them, the UIC 406 method, in a practice case. The practice case consist of adding two new trains in an already calculated schedule for the increment of the use of a line, using the new techniques for automatically detect the conflicts that appear after adding these new trains and solving the conflict. This paper will also present the statistical of how passenger's train demand increases passengers flow.
\end{abstract}

Keywords: railways line; capacity consumption; train graph; compression of train graph; multiagent solution; iterative application.

\section{Introduction}

The significance of transport is very high for any branch of economy and is increasingly growing as worldwide globalization takes place when countries situated in different continents are linked with the relationships of trade and free movement of people. Competing with other means of transport, railway transport has to improve the quality of carriage of people and freight. To reach this aim, railway network is being developed, the quality of rolling stock is improved and carriage process is perfected.

Several research studies of passenger transportation by railways were made by Dailydka and Lingaitis [1], Sun and Xu [2]. Different studies by Maskeliūnaite and Sivilevičius [3], [4] determined that it is very important to have methodology for determining and evaluating of carriage of passengers by different trains that must be based on objective data. As part of studies the General recommendation is the use of multiple criteria model for international train quality evaluation, taking into account that the quality index in the train traffic also depends on the track quality that has a large impact on train parameters that must be taken into account for the increasing of the line [5].In order to increase the train traffic it is necessary to improve railway line capacity [6]. Li [7] recommended the train routing model and algorithm combined for planning new traffic train graph. Lai [8] described two common capacity evaluation methods: parametric capacity analysis and simulation.

$\mathrm{Hu}$ and Lin analyzed the train arrival impact on the frequency of accidents on roads and rail crossings at inclines [9]. Though a number of deaths at level crossings amount to only $2 \%$ of the total number of road deaths, it makes $20-30 \%$ of the total deaths in Railway [10].

According to recent studies, JSC "Lietuvos geležinkeliai" (further LG) objectives are focused on ensuring the needs of railway transportation up to 2040 and assuring:

Corresponding author: Larisa Valentinovič. E-mail address: larisa103@gmail.com

http://dx.doi.org/10.3846/enviro.2014.174

(C) 2014 The Authors. Published by VGTU Press. This is an open-access article distributed under the terms of the Creative Commons Attribution License, which permits unrestricted use, distribution, and reproduction in any medium, provided the original author and source are credited. 
- Local habitants needs.

- Transport connections with the EU and other countries.

- Transit transport crossing the territory of Lithuania.

- Railway network capacity increase.

In 2013 LG transported about 4.87 million passengers (more than 1\% than in the year 2012). The local passenger transportation volume is 3.8 million, international passenger transportation 520 thousand and transit 543 thousand. According to these data more and more passengers are using the rail transport.

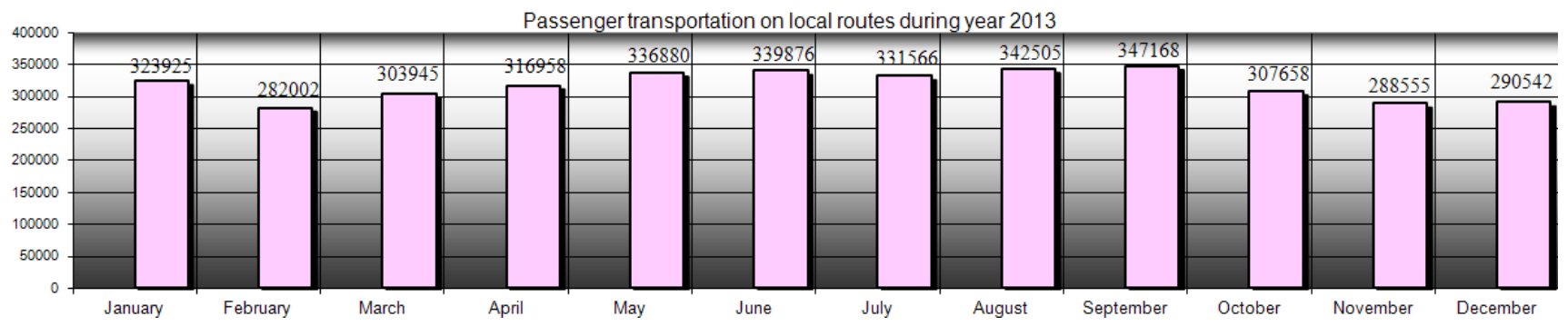

Fig. 1. Passenger transportation on local routes during the year 2013

According to passenger transportation forecast, till 2040, even the pessimistic forecast data demonstrate that the passengers' transportation is expected to be increased by international transportation and local routes (see the forecast data on Table 1 and Table 2). This forecast is supplemented with the fact that the implementation of "Rail Baltica" project and the establishment of new transit passenger terminal in Kaunas (and later in Vilnius), are based on the expectation of an increment in the flow of international passengers, travelling from neighboring and remote Asian countries to Western European countries through the Lithuanian territory [11] (see Table 1. The forecast of international passengers' transportation by Lithuanian Railways till the year 2040 and Table 2. Forecast of local passengers' transportation by Lithuanian Railways on local routes till the year 2040). Therefore it is one of reason to improve Traffic Management.

Table 1. The forecast of international passengers' transportation by Lithuanian Railways till the year 2040

\begin{tabular}{lllll}
\hline \multicolumn{1}{c}{ Forecast } & 2010 & 2020 & 2030 & 2040 \\
\hline Basic & 789,6 & 1245,2 & 1704,4 & 1836,6 \\
Optimistic & 857,5 & 1672,6 & 2289,3 & 2466,9 \\
Pessimistic & 764,1 & 801,2 & 985,6 & 1177,7 \\
"Black" & 735,2 & 592,9 & 288,4 & 44,2 \\
\hline
\end{tabular}

Table 2. Forecast of local passengers' transportation by Lithuanian Railways on local routes till the year 2040

\begin{tabular}{lllll}
\hline \multicolumn{1}{c}{ Forecast } & 2010 & 2020 & 2030 & 2040 \\
\hline Basic & 3278,3 & 4713,7 & 5523,4 & 6129,6 \\
Optimistic & 3560,4 & 5474,3 & 7350,1 & 8958,0 \\
Pessimistic & 3172,6 & 3229,8 & 3859,1 & 4611,6 \\
"Black" & 3093,4 & 921,7 & 274,6 & 81,8 \\
\hline
\end{tabular}

The expected effect in a long-term perspective can be achieved by means of international transportation modernization and acceleration of traffic speed. The improvement of economic relations between Lithuania, neighboring and remote countries also will help in the achievement of this perspective.

For this purpose it is necessary to remodel equipped railway infrastructure, traffic safety organization and control, and make them appropriate for modern trains, flexible schedules, high traffic speed, attractive ticket prices and convenient journey conditions, all of them in coordination with other transport mode and other actuation in the system.

According Luethi building new infrastructures is the most obvious possibility to increase capacity. However, this is expensive and, particularly in bottleneck and station areas, often no longer possible. Therefore, production-based strategies for increasing capacity must be developed (i.e. based on how trains are operated). These strategies essentially allow more trains to be operated on the same infrastructure [12].

According Schobel the design of the railway infrastructure is strongly related with the demand of expected traffic which is defined by a timetable. Therefore, the timetable predicts the infrastructure layout. The timetable is calculated taking into account the topology of the railway network and different time slots that assures the train movement and the safety [13].

In order to increase the number of trains operated, the headway (time) between trains must be decreased. The headway between trains is determined by two components: safety and schedule reliability. The safety component ensures that trains 
get separated one from the other with enough distance to prevent collisions. The schedule reliability component is designed to provide reserve (or buffer) time necessary to ensure that trains remain on schedule (i.e. it reduces the impact of delays on system-wide operations).

The process of developing new timetable and communicating them to all affected parties is complex and time consuming. This is why schedule planners add reserve time to timetables. Thereby, three types of reserves were distinguished:

- Reserves for the driving accuracy.

- Reserves for the running times.

- Operational Reserves (reserves between trains) to handle larger delays.

Therefore, reserve time allows both, to reduce the need for rescheduling and to simplify the process of rescheduling. However, reserve time wastes capacity. If it was possible to reduce the amount of reserve, the time network capacity could be increased without constructing new infrastructure. Thus, research about optimizing the amount and distribution of reserves in railroad networks is a key factor of success [12].

The line capacity is also affected by the maintenance type: preventive and corrective. While the first maintenance is scheduled and introduced in the train graph, the capacity of the network is reduced by these trains even more if we take into account that old installation (as actual Lithuanian railway network) requires more preventive maintenance. The second one is unscheduled and can generate conflicts with already scheduled trains that must be solved immediately to assure the rest of the schedule. For these two reasons it is necessary to implement a system that allows the network use optimization and that provides planners with a flexible and powerful conflict resolution module.

Efficient traffic management support systems need to compile actual monitoring data on train positions, headways and detect automatically conflicts between trains in advance, in order to support dispatchers by regularly the actual timetable, Incorporating standard conflicts between only two trains might be solved automatically, whereas route conflicts in heavily occupied networks and complex stations require accurate real-time simulation and optimization of dispatching options according to their expected performance. The effectiveness of different measures may be evaluated and ranked on the basis of the total amount of consecutive delays, links and stations affected and the time to fade out. More detailed, accurate and continuous traffic information with regard to actual deviation from the train schedule, location of trains ahead and occupation and release of block and route sections can help train drivers to anticipate and solve conflicts better [14].

With allowances made for the fact that LG is planning to establish a new TMC in April 2014, new objectives are set, such as railroad traffic organization, railroad traffic schedule optimization, maximum exploitation of railroad infrastructure, freighter's traffic organization strictly in accordance with the schedule, non-standard situations resolution from the single traffic management center and traffic safety ensurance.

Solutions to these and other issues may be achieved only by means of technological integration of traffic management systems, which are substantiated by modern informational technologies. The new integrated management system, based on the development and the trends of smart technologies which have become dominant not only in Lithuania, but in the whole world is being created. Therefore supervision and control over the new signalization systems are very important issues in the field of railroad transport.

Main trends proving the need of traffic management system improvement are:

- All new infrastructure projects.

- Improvement of the informational system.

- Priority to the new international routes of various kinds: technological, container-type, cargo type-based and singleoperator trains.

- Change of car planning system due to the increased fleet of private cars.

- Work performance improvement.

- Drafting up of a new railway schedule for the trains going by the "Rail Baltica" railways of the European gauge.

The train graph must be created according to the effective capacity for the particular line. In different situations it is possible to use different methods for calculating the railway capacity. The current calculation method used in LG is an old method that must be improved or renewed. The new system uses the UIC 406 methods which the standard UIC leaflet "Capacity" recommends as a procedure to evaluate the infrastructure occupation. It is fast and effective way to evaluate the capacity utilization of railway line. Wahlborg analyzed the capacity calculation according to the UIC capacity leaflet that is broadly used in European Railway companies [15]. Lai described the comprehensive decision support framework, based on three stand-alone tools, for strategic railway capacity planning in North America: "Alternatives Generator", "Investment Selection Model" and "Impact Analysis Module" [16]. In all cases, analytical methods, optimization and simulation are the three general methodologies for the capacity management. According to Zhang, the analytical methods may be a good start for optimization methods and represent a preliminary solution [17]. The optimization and simulation method need to be adapted to each application environment to obtain a desired train schedule and validation.

\section{Line capacity calculation, modules and their analysis}

Different capacity definitions are used in the railway market:

- "The ability of the Cartier to supply as required the necessary services within acceptable service levels and costs to meet the present and projected demand" - Kahan. 1979 [18]. 
- "Capacity is the highest volume (trains per day) that can be moved over a subdivision under a specified schedule and operating plan while not exceeding a defined threshold" - Kruger. 1999 [19].

- "Capacity is measured as the count of valid train paths over a fixed time horizon within an optimal master schedule." Harod. 2009 [20].

- "The maximum number of trains that may be operated using a defined part of the infrastructure at the same time as a theoretical limiting value is not reached in practice." - Hancen et al. 2008 [21].

- "A unique, true definition of capacity is impossible." - 2004 [22].

Traditionally in Lithuania the capacity of the railway line is described as follows: "The maximum amount of freightliner trains of certain mass and length (train-pairs) which can pass this railroad line within a time unit (a day, an hour) with allowances made for railroad line technical equipment and railroad traffic organization method."

Railroad line capacity depends on many factors (see Fig. 2. Capacity dependences):

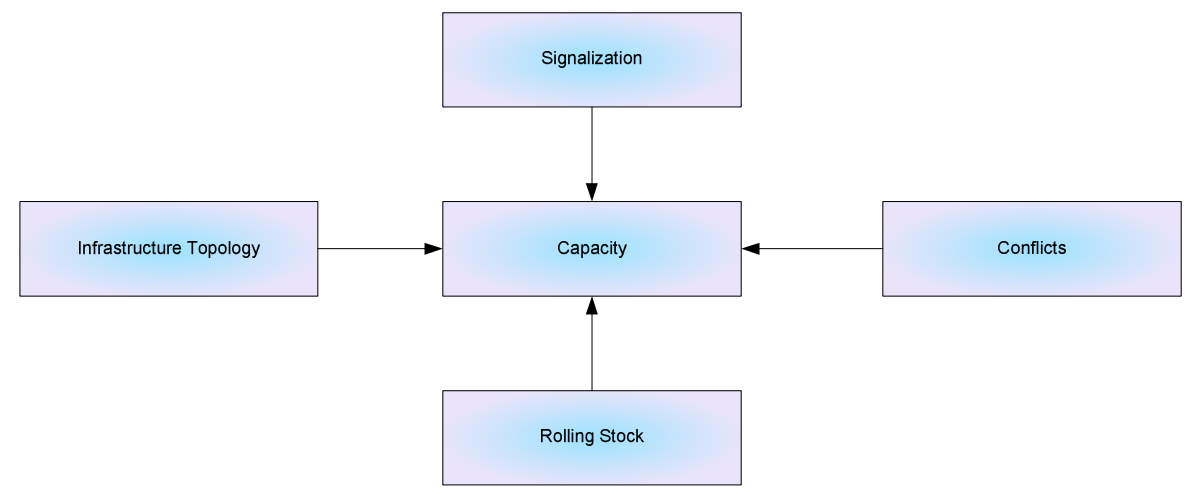

Fig. 2. Capacity dependences

Factors that can affect the capacity of the line, according to Fig. 2 Capacity dependences are:

- Rolling stock has influence on the speed, acceleration and deceleration time.

- Infrastructure topology influences on Railway capacity. Levelling-off of rise and fall, construction of the second way for the single way section between the stations, railway extension allow to increase the capacity of stations and sections between them.

- Signalization equipment. Semi- automatic signalization system allows only one train to be in a lineside and when there is a long distance between station, the one lineblock can cross only be only 2-3-trains in 1 hour. For example, the capacity of the line with a semi-automatic system may be 2-2.5 times smaller than lines with automatic.

- Conflicts may compress traffic trains graph to the point where the average speed drops and correspondingly it reduces line capacity.

\subsection{Actual Method}

At present, an analytical method is used in Lithuania for calculation of railroad line capacity as described in the methodological literature [23].

The formula for calculating the line capacity in single line with an automatic lineblok (1AB) is:

$$
\mathrm{N}_{1 \mathrm{AB}}=\frac{0,4 \mathrm{~T}}{\mathrm{I}}
$$

The formula for calculating the line capacity in double line with an automatic lineblok (2AB) is:

$$
\mathrm{N}_{2 \mathrm{AB}}=\frac{0,85 \mathrm{~T}}{\mathrm{I}}
$$

where: $\mathrm{N}$ - capacity of the line; $\mathrm{T}$ - Minutes in a Day (1440); I - minimum interval between the moving trains (minutes).

The calculation of the capacity is based on the calculation of the factor $I$ that is the shortest period of time necessary for trains to move in sequence within the sections between the stations and to create conditions for trains to move at the set speeds.

The formula for calculating the factor $I$ is:

$$
\mathrm{I}=0,06 \frac{\left(3 \mathrm{~L}_{\mathrm{b}}+\mathrm{L}_{\mathrm{t}}\right)}{\mathrm{V}_{\mathrm{vid}}}
$$


whereas: $\mathrm{L}_{\mathrm{b}}$ - inner length of blocking district, (meters); $\mathrm{L}_{\mathrm{t}}$ - average length of a train, (meters); $\mathrm{V}_{\text {vid }}$ - average speed within the railroad district, $(\mathrm{km} / \mathrm{h}) ; 0,06$ - passing rate.

For the calculation purposes, the length of a train shall be selected in accordance with the standard lengths in meters: $850,950,1050,1150$ or 1250 . Railroad district capacity shall not exceed the capacity of separate districts elements.

During the process of the automatic lineblock system design, stoplights were provided for those which were to be mounted in accordance with the selected interval $I$. In case of change of operation conditions (moving speeds, locomotive engine type, train mass, etc.), interval I must also be changed. Therefore, due to the modern types of locomotive engine equipment, especially when using electric trains with high moving speeds, interval $I$ between the trains may be decreased to 6-8 min and to 4-5 minutes within the uptown railway regions near the major centres.

\subsection{Metro-Train Method}

The second analyzed method for increasing the capacity of the line is to use the simple peak and valley time type. This method is based on reducing freight and slowing trains and prioritizing passenger and fast trains during peak time of the day. For example, as the number of passenger trains within the railway district Kazlų Rūda - Kaunas and later Kaunas Vilnius is planned, we can recommend using the method of "Metro-train schedule" during the peak-hours. It was proven that line capacity depends on the train type (design speed). It is possible to overview and compares two different options. E.g. from 6 am. to $7.30 \mathrm{am}$. and from $4.00 \mathrm{pm}$. to 5:30 pm. to allow the passenger trains only. Two schedules will show the difference between the number of trains within the set period.

Next figure (see Fig. 3. Combined schedule versus Metro-Train schedule) reports the comparison in the train graph between the normal scheduled train and the metro-train compression method.
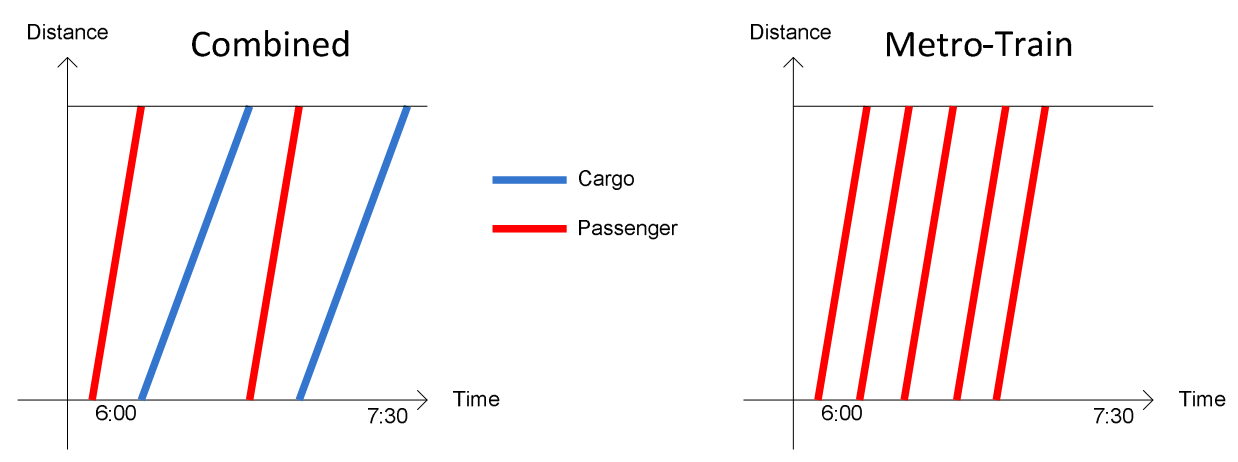

Fig. 3. Combined schedule versus Metro-Train schedule

The advantage of this method is easy to implement and calculate as all trains go at the same speed in double track linesides with automatic lineblock and it is possible to depart trains one after another at the interval of almost two blocks.

The disadvantages is that in Lithuania there is an intensive passenger traffic is in the same section and time as the intensive cargo traffic, therefore some wagons may not be moved and delays of locomotives crews and cargo delivery may occur. So it is not recommendable to use of this compression (optimization) method in this case.

\subsection{UIC 406 Method}

The UIC 406 standard defines a method to measure the available capacity that a railway infrastructure has. This UIC 406 method is widely used (implemented) in the European railways. The capacity is measured by the number of trains that can run along the infrastructure per unit of time. As the UIC 406 standard explains the capacity is influenced by several factors:

- The signaling of the infrastructure.

- The average speed of the trains.

- The stability needed by the administrator in order to avoid huge disruptions in case of minor delays.

- The heterogeneity of the traffic. That means the balance between the number of faster trains and the number slower trains.

The compression process follows under some simple rules:

- All train paths are pushed together up to the minimum headway according to their timetable order, without buffer times.

- The running times, overtaking, crossing, stopping times are not changeable.

- Any occupation time must be incorporated. Also indirect occupation times (times occupied and not available for further train paths). 


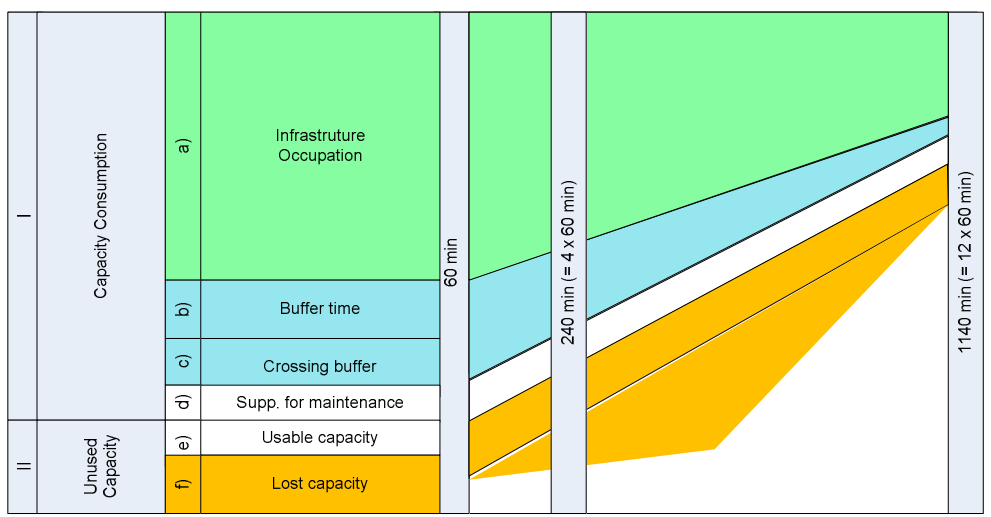

Fig. 4. Determination of capacity consumption - UIC 406 R [24]

The capacity consumption is the sum of the infrastructure occupation and the buffer time (plus other supplements) as it is shown in the drawing on Fig. 4. Determination of capacity consumption - UIC 406 R [24]. It may be determined on the basis of compressed timetable, using the following formulas [25]:

$$
\mathrm{K}=\frac{\mathrm{k}}{\mathrm{U}} \cdot 100
$$

and

$$
\mathrm{k}=\mathrm{A}+\mathrm{B}+\mathrm{C}+\mathrm{D}
$$

where: $\mathrm{K}$ - capacity consumption (\%); U - chosen time window (minutes) (parts I+II in Fig. 4 Determination of capacity consumption - UIC $406 \mathrm{R}$ ); $\mathrm{k}$ - total consumption time (minutes); A - infrastructure occupation (minutes); B - buffer time (minutes); C - supplement for single-track lines (minutes); D - supplement for maintenance ( $\mathrm{min})$.

The compression process is applying for:

- Help of the optimal planning of trains during the long time maintenance infrastructure work.

- Improving the utilization of the railway infrastructure.

- Unscheduled trains planning.

- Optimized turnover of the rolling stock and the crew.

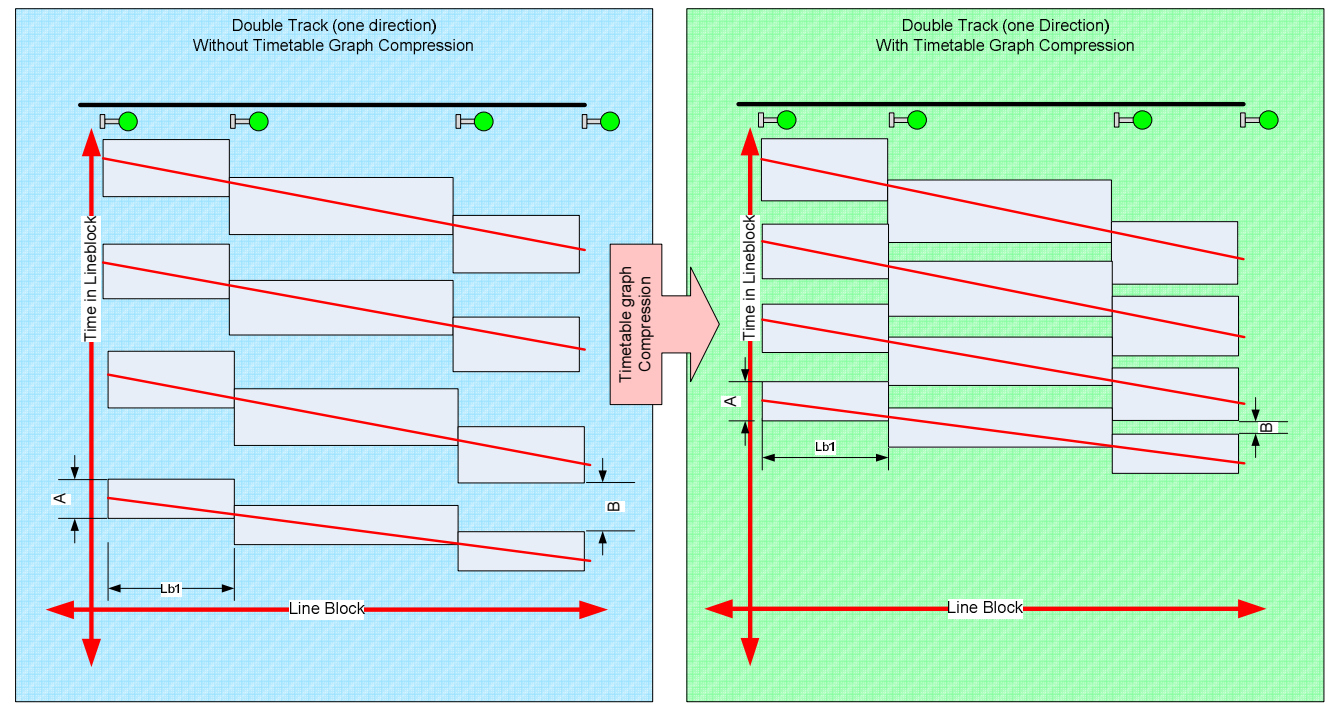

Fig. 5. Double track compression [26]

The result of the compression can be analyzed in Fig. 5. Double track compression [26]. In the picture it can be distinguish between the train graph before the compression and after the compression method have been applied. 


\section{Method Implementation}

\subsection{Method Implementation}

For the implemented UIC 406 method it is necessary to split the development into several modules. Some of the modules have been drawn in Fig. 6. Modules implementation.

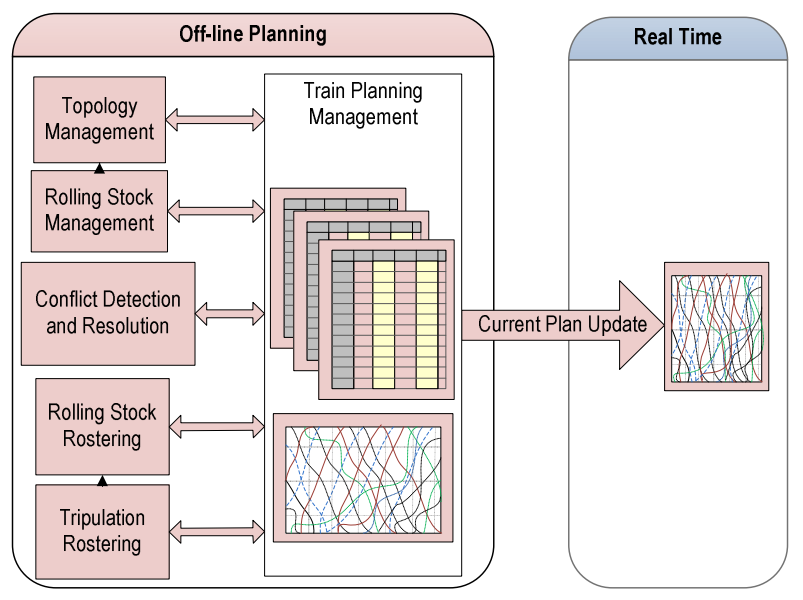

Fig. 6. Modules implementation

In the above mentioned Figure the system is divided into different modules for the Off-line Planning environment:

- Topology module. - This module maintains the topology of the railway network updated according to the installation (curves, slopes, distances, etc).

- Rolling Stock Management Module. It is - a subsystem, making it possible to introduce the properties of locomotives, wagons, electric trains and self-propelled vehicles into the system, and to perform their connection (create train compositions).

- Conflict detection and resolution module. It is - one of the most important real-time modules. It helps in automating solutions due to the increase of passenger trains intensity and speed, non-standard situations will become more complicated and demand faster and more efficient conflict settlement. Human factor must be minimized.

- Rolling Stock rostering module. - This module analyzes the availability of the different rolling stock in a similar way to Topology module.

- Tripulation rostering module. - This module is similar to Rolling Stock but related with tripulation.

\subsection{Modules Development.}

New development techniques are based on distributed software that allows modules to work as separate agents. The multiagent technique is based on the use of different agents that works separately for obtaining the final result.

Agents may interact in this way making a multiagent system. Thereby they may perform complicated, multifold tasks and perform specialized functions more efficiently. The multiagent systems face strict requirements, as their abilities of perception, initiative, communication, etc. must be as similar to the human ones as possible. It is especially important for the information business as customers are looking only for that information which appears important to them. It must be updated, precise and useful, adapted for different purposes. The multiagent systems must be useful, consumer-oriented and, of course, reliable, possessing the property of learning capacity and the ability to adapt to constantly changing consumer objectives and environment.

One of the multiagent system purposes in railways is that it helps managing devices, adopts decisions independently, without human interference.

During the conflicts, when it is necessary to repeatedly check the changes in the railway traffic, an interactive method is used. E.g., if the railway traffic replanning is needed, - the system uses the response-to-situation function within the system, and the situation improves at every remove.

During the first step the system coarsely calculates the railway traffic schedule, planning only the way, including the locking districts to be passed by the trains (at this step a conflict in the actual schedule is possible, where two different trains may pass the same locking district). During the second step the system identifies the conflicts and solves them in accordance with the railway traffic priorities. During the third step optimal railway traffic schedule with all delays in complicated situations is drafted up in accordance with the railway traffic priorities. The second and the third steps are repeated till the system recalculates and drafts up the railway traffic schedule, which would satisfy all traffic and safety requirements. It is always possible to change railway traffic priorities, forcing the system to calculate the railway traffic. In accordance with 
the schedule, automated systems may allow minimizing the distance between the trains and let pass additional trains thus and consequently increasing the district capacity.

\subsection{Analysis of potential impact of non-standard situations on the valid schedule.}

Any discrepancy from the valid schedule may be called - "Non-Standard Situation".

The system is aimed at overviewing and correcting railroad traffic schedule timely and rationally. It is especially important to adapt the function of electronic schedule correction in the intense-traffic lines which are run and will be run by express passenger trains. On all occasions when it is necessary to change (compress) the railroad schedule, first of all, there is an employee is in charge of drafting up the schedule who must analyze it according to visual data, if theoretically it is possible to include an additional train into the basic schedule. After the analysis follows next task to add a new train for the same route with all new information related to the new train as speed, mass, and other main information related with the route (station, times to stop, etc.). Then the planning module uses all the provided information for a precise and correct calculation of the train's route. The analysis is conducted and provided with two different railway schedules. The first one is valid, the other one is provided with the compressed railway schedule allowing to insert two more passenger trains moving at an increased speed.

For this analysis a train traffic schedule in the section Jiesia - Kazlų Rūda is used, in the time range starting at 15:30h (see

Fig. 7. Actual train graph). The analysis consists of trying to insert two fast trains circulating to another country from the west European countries.
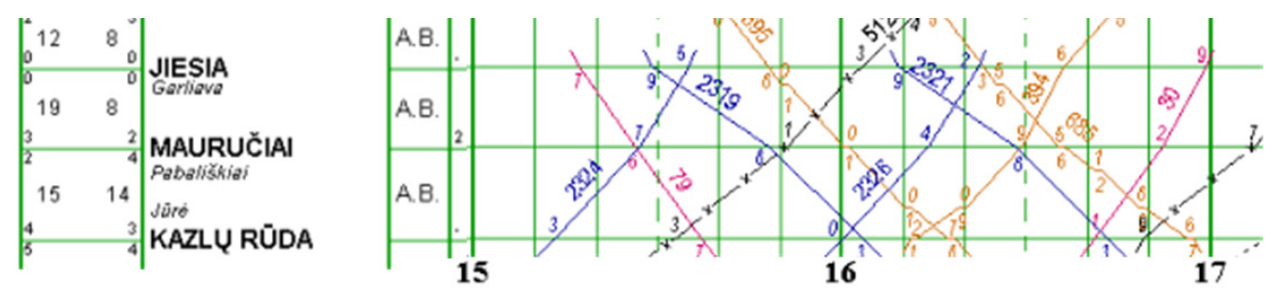

Fig. 7. Actual train graph

The first fast train, TEST1, passes Jiesia at 15:25 h. The next scheduled train, 2319, passes Jiesia at 15:29 h. The system calculates that it will take 7 minutes for the fast train to go from Jiesia to Mauručiai, running at $140 \mathrm{~km} / \mathrm{h}$. However, the train graph displays that there would be a conflict with the following train 2319 . The conflict is displayed in an orange rectangle indicating the conflict type (see Fig. 8. Conflict detection and Fig. 9. Time schedule with detected conflict).

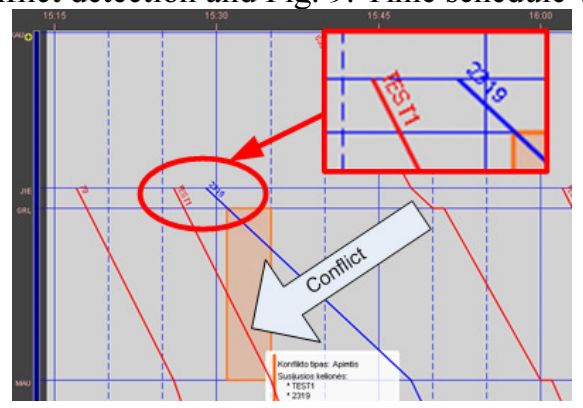

Fig. 8. Conflict detection

\begin{tabular}{|c|c|c|c|c|c|c|c|c|c|c|c|}
\hline \multicolumn{6}{|c|}{ Identifikacija } & \multicolumn{4}{|c|}{ Apskaičuoti laikai } & \multicolumn{2}{|r|}{ Priimti laikai } \\
\hline Tipas & \multicolumn{2}{|c|}{ Traukinio numeris } & Mazgo kodas & Mazgas & Distancija (hm) & Mažiausias laikas & Bazinis laikas & UIC & Laiko tipas & Maršruto/keleivinis sustojimas & Techninis sustojimas \\
\hline D & TEST 1 & \multirow[t]{5}{*}{4} & 12311 & Jiesia & & & & & & & $00: 00$ \\
\hline 8 & & & & & 109 & 04:41 & $06: 21$ & & $07: 0$ & 07:00 & \\
\hline & & & 12320 & Mauručıai & & & & & & & \\
\hline 8 & & & & & 176 & 07:33 & 09:43 & & $10: 0$ & 10:00 & \\
\hline D & & & 12340 & Kazlụ Rūda & & & & & & & \\
\hline
\end{tabular}

Fig. 9. Time schedule with detected conflict

The minimum time between Jiesia and Mauručiai consist of 04:41 minutes, without recovery margins, supplementary margins, infrastructure speed limits or technical limitations of the rolling stock. Therefore it is valid if in this lineside we reduce the time to 5 minutes (see Fig. 10. Time reduction). The blue colour on the table informs the planner that the time for this lineside is shorter than the basic time. The system allows solving the conflict automatically or manually. 


\begin{tabular}{|c|c|c|c|c|c|c|c|c|c|c|c|}
\hline \multicolumn{6}{|c|}{ Identifikacija } & \multicolumn{4}{|c|}{ Apskaič̀uoti laikai } & \multicolumn{2}{|r|}{ Primti laikai } \\
\hline Tipas & Trauk & & Mazgo kodas & Mazgas & Distancija $(\mathrm{hm})$ & Mažiausias laikas & Bozinis laikas & UIC & Laiko tipas & Maršruto/keleivinis sustojimas & Techninis sustojimas \\
\hline D & TEST 1 & 4 & 12311 & Jiesia & & & & & & & 00:00 \\
\hline 8 & & & & & 109 & $04: 41$ & $06: 21$ & & $07: 0$ & $05: 00$ & \\
\hline & & & 12320 & Mauručiai & & & & & & & \\
\hline 8 & & & & & 176 & 07:33 & $09: 43$ & & 10:0 & 10:00 & \\
\hline D & & & 12340 & Kazlụ Rūda & & & & & & & \\
\hline
\end{tabular}

Fig. 10. Time reduction

After reducing this lineside time we eliminate the conflict for the first fast train TEST1. In a similar way the second fast train TEST2 is inserted in the traffic schedule. The next picture (Fig. 11. Final result) shows the traffic train graph with the two additional fast trains inserted, as the result of applying compression methods.

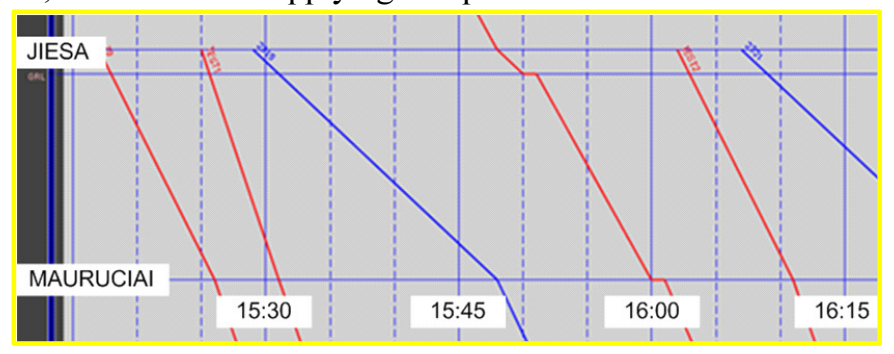

Fig. 11. Final result

The results after the analysis and compression made for both trains are entered in Table 3. Current timetable and Table 4 Timetable after compression.

Table 3. Current timetable

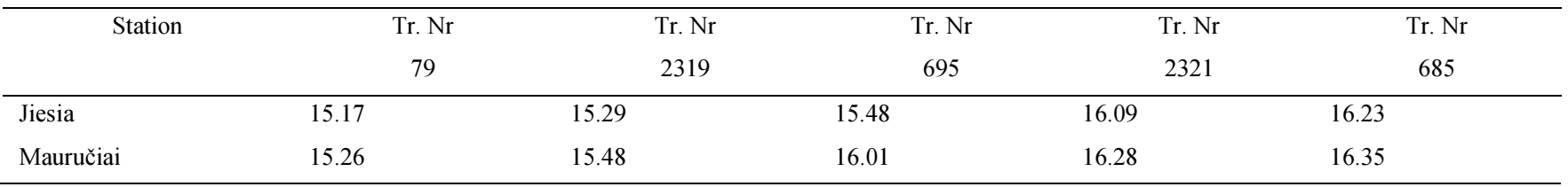

Table 4 Timetable after compression

\begin{tabular}{lcccccc}
\hline \multicolumn{1}{c}{ Station } & Tr. Nr & Additional & Tr. Nr & Tr. Nr & Additional \\
& 79 & Test1 & 2319 & 695 & $\begin{array}{c}\text { Tr. Nr } \\
\text { Test2 }\end{array}$ & 685 \\
\hline Jiesia & 15.17 & 15.25 & 15.29 & 15.48 & 16.03 & 16.09 \\
Mauručiai & 15.26 & 15.31 & 15.48 & 16.01 & 16.11 & 16.28 \\
\hline
\end{tabular}

\section{Conclusions}

Rapidly growing passenger carriage volumes demand new passenger carriage routes and schedules. A valid railway traffic schedule may change several times a year. The new TMC will have the function allowing compressing the valid railway traffic schedule.

Improvement and modernization of the transport sector of Lithuanian Railways, part of them is the establishment of a new TMC, will assist in a better integration to the EU transport system. As soon as the "Rail Baltica" project is finished, the train traffic speed can be increased up to $160 \mathrm{~km} / \mathrm{h}$. Technical properties of the new generation of passenger trains will ensure keeping high speed but this new situation will have a direct impact of the line capacity. Intense railway districts could be passed by a bigger number of passenger trains. The new technology used for train planning will ensure traffic efficiency and flexibility, infrastructure capacity will be improved and the inner speeds can be increased. The new TMC will not only strengthen the position of LG in the transport systems of the nearest countries, but will also keep up its competitive ability in the Baltic States.

In this regard, the objective of the current study is to provide an analysis between the old (Eastern) line capacity calculation method and the European UIC 406, and CUI Timetable Compression Methods. As concerns highly increased passenger trains volumes within the territory of Lithuania (especially within the railway district Vilnius-Kaunas), the "Metro-train" method is acceptable when used in respect of peak hours.

The analysis for the purposes of increasing of Kazlų-Rūda-Kaunas line capacity was also conducted. Two new trains which will run on routes Vilnius-Kaunas-Warsaw and Vilnius-Kaunas-Berlin once the "Rail Baltica" is implemented were added to the actual schedule. The example shows that the new system is able to calculate the train schedule nearer to the 
minimum mark (decrease the buffer time). The new System also informs the planner about the risks of the traffic safety and does not let decrease the acceptable speed below a certain limit.

The article provides the description of a new multiagent system, which will put together the main functions of the TMC improvement. Every module works individually as a separate agent, but the final result comes down to a single real-time module, which will implement the main organization of railway traffic management.

The new System based on multiagent development procedures will: shorten the response period, increase flexibility and operational efficiency when adopting decisions in case of unplanned events. It will also increase the efficiency of infrastructure use, decrease human intervention when replanning railway traffic and ensure traffic safety.

Therefore time for adding new trains in an traffic train graph already calculated, is reduced as the new method together with the use of technologies help planner to: calculate new schedule, determine possible conflicts, offer to planner different solutions for each conflict and recalculate new schedule.

\section{References}

[1] Dailydka, S.; Lingaitis, L.P. 2012. A study on the options of means for railway passenger transportation, Transport Problems-Problemy Transportu 7(1): 53-62.

[2] Sun, Y.; Xu, R. 2012. Rail transit travel time reliability and estimation of passenger rout choise behavior. Analysis using automatic fare collection data, Transportation Research Record 2275: 58-67. http://dx.doi.org/10.3141/2275-07

[3] Maskeliūnaitè, L.; Siviliavičius, H. 2012. Expert evaluation of criteria describing the quality of travelling by international passenger train: technological, economic and safety perspectives, Technological and Economic Development of Economy 18(3):544-566. http://dx.doi.org/10.3846/20294913.2012.710178

[4] Sivilevičius, H.; Maskeliūnaitè, L.; Petkevičienè, B.; Petkevičius, K. 2012. The model of evaluating the criteria, describing the quality of organization and technology of travel by international train, Transport 27(3): 307-319. http://dx.doi.org/10.3846/16484142.2012.724448

[5] Xu, P.; Sun,Q.; Llu, R.; Wang,F.2011. A short range prediction model for track quality index. Proceeding of the Institution of Mechanical Engineers, Part F, Journal of Rail and Rapid Transit 225(3): 277-285. http://dx.doi.org/10.1177/2041301710392477

[6] Sameni, M. K.; Preston, J. 2012. Value for railway capacity assessing efficiency of operators in Great Britan, Transportation Research Record 2289: 134-144. http://dx.doi.org/10.3141/2289-18

[7] Li, F.; Gao, Z.; Wang, D.Z.W. 2013. Train routing model and algoritm combined with train scheduling, Journal of Transportation Engineering 139: 1. http://dx.doi.org/10.1061/(ASCE)TE.1943-5436.0000461

[8] Lai, Y.-C.(R).; Liu, Y.-H.; Lin, T.-Y. 2012. The Development of Base Train Equivalents to Standardize Trains for Capacity Analisys. Transportation Research Record 2289:119-125. http://dx.doi.org/10.3141/2289-18

[9] Hu, S.-R.; Lin, J.-P. 2012. Effect of train arrival time one crash frequency at highway-railroad grade crossings. General classification regression model, Transportation Research Record 2298: 61-69. http://dx.doi.org/10.3141/2298-07

[10]Gailiené, I.; Skerys, K.; Ciparyte, G. 2013. Investigation of traffic safety situation at the level crossings in Lithuania, The Baltic Journal of Road and Bridge Engineering 8(2): 117-123. http://dx.doi.org/10.3846/bjrbe.2013.15

[11] Griškevičienè, D.; Griškevičius, A.;Griškevičiutè-Gečienè, A. 2011. Peculiarities of passenger flows forecast on the reduced market conditions, in selected papers of the 8th International Conference "Environmental Engineering” 3: 898-904.

[12]Luethi, M.; Nash, A.; Weidmann, U.; Laube, F.; Wuest, R. 2007. Increasing Railway Capacity and Reliability through Integrated Real-Time Rescheduling, in Proceeding of the $11^{\text {th }}$ World Conference on Transport Research. Berkeley.

[13] Schobel, A.; Besau, G.; 2012. Timetable Based Design of Railway Infrastructure, in 20th International Symposium. Žilin

[14]Hansen, A.; 2009. Railway Network Timetabling and Dynamic Traffic Management, in selected papers of the 2th International Conference on Recent Advances in Railway Engineering, 135-145.

[15]Wahlborg, M. 2004. Banverket experience of capacity calculations according to the UIC capacity leaflet, Computers in Railways IX: 665-673.

[16]Lai, Y.-C.; Barkan, C. P. L. 2011. Comprehensive decision support framework of strategic railway capacity planning, Journal of Transportation Engineering 137(10): 738-749. http://dx.doi.org/10.1061/(ASCE)TE.1943-5436.0000248

[17]Zhang, J.; Han, B.; Nie, L. 2011. Research on capacity calculation and assessment framework for Chinese high speed railway based on UIC 406, Journal of System and Management Sciences 1(6): 59-75.

[18]Kahan, A. M. 1979. Railway capacity analysis and related methodology, Canadian transport commission: Ottawa/Hull, Canada.

[19]Krueger, H. 1999. Parametric modelling in rail capacity planning, Proceedings of the 1999 Winter Simulation Conference, 1194-1200.

[20]Harrod, S. 2009. Capacity factors of a mixed speed railway network. Transportation Research Part E: Logistics and Transportation Review 45(5): 830 841. http://dx.doi.org/10.1016/j.tre.2009.03.004

[21]Hancen, I. A.; Pachl, J. eds. 2008. Railway timetable and traffic. Eurailpress: Hamburg.

[22] UIC. 2004. Capacity (UIC code 406). International Union of Railways (UIC): Paris, France.

[23]Petrenko, V. 2012. Geležinkelio eismo sauga: praktiniu darbu metodikos nurodymai. Vilnius Gediminas Technical University. Vilnius: TECHIKA. ISBN 978-609-457-196-1. http://dx.doi.org/10.3846/1303-S

[24]Landex, A. 2008. Methods to estimate railway capacity and passenger delays, in Department of Transport. Technical university of Denmark: Kgs. Lyngby.

[25] Stock, R. 2008. Estimation of railway capacity consumption using stochastic differential equations. University of Trieste.

[26]Landex, A.; Kaas, A.H.; Jacobsen, E.M.; Schneider-Tilli, J.; 2007. The UIC 406 capacity method used on single track sections, in Proceeding of the 2th International Seminar on Railway Operations Modelling and Analysis, eds. I.A. Hansen, A.Radtke, J.P. Pachl, E. Wendler, Germany. 